Preliminary Study of the 1991 Oakland Hills Fire and Its Relevance to Wood-Frame, Multi-Family Building Construction

Kenneth D. Steckler

David D. Evans

Jack E. Snell

$-Q C$

United States Department of Commerce

National Institute of Standards and Technology

100

.456

\#1424

1991 
NATIONAL INSTITUTE OF STANDARDS \& TECHNOLOGY

Research Information Center

Gaithersburg, MD 20899 


\section{Preliminary Study of the 1991 Oakland Hills Fire and Its Relevance to Wood-Frame, Multi-Family Building Construction}

Kenneth D. Steckler, David D. Evans and Jack E. Snell

Building and Fire Research Laboratory

Gaithersburg, MD 20899

November 1991

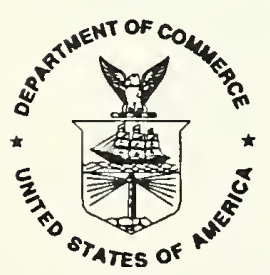

U.S. Department of Commerce

Robert A. Mosbacher, Secretary

National Institute of Standards and Technology

John W. Lyons, Director 

LIST OF TABLES $\ldots \ldots \ldots \ldots \ldots \ldots \ldots \ldots \ldots \ldots \ldots \ldots \ldots \ldots \ldots \ldots \ldots$

LIST OF FIGURES $\ldots \ldots \ldots \ldots \ldots \ldots \ldots \ldots \ldots \ldots \ldots \ldots \ldots \ldots \ldots \ldots \ldots$

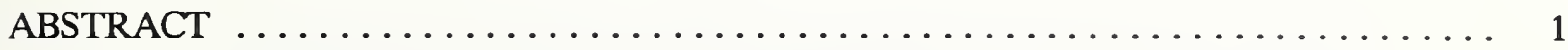

1.0 INTRODUCTION $\ldots \ldots \ldots \ldots \ldots \ldots \ldots \ldots \ldots \ldots \ldots \ldots \ldots \ldots \ldots \ldots \ldots$

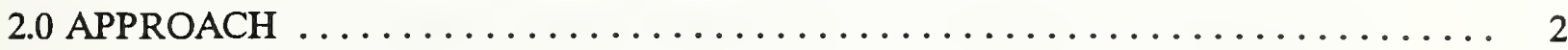

2.1 PARTICIPATING U.S. AND JAPAN EXPERTS $\ldots \ldots \ldots \ldots \ldots \ldots \ldots \ldots \ldots$

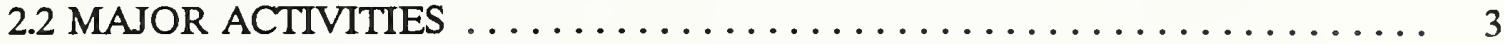

2.2.1 Visits To The Fire Site $\ldots \ldots \ldots \ldots \ldots \ldots \ldots \ldots \ldots \ldots \ldots \ldots$

2.2.2 Meeting With The California State Fire Marshal ............ 3

2.2.3 Meeting With Researchers At The University Of California, Berkeley . . 4

2.2.4 Meeting With Oakland Building Official ............... 4

2.2.5 Wrap-up Meeting ..................... 5

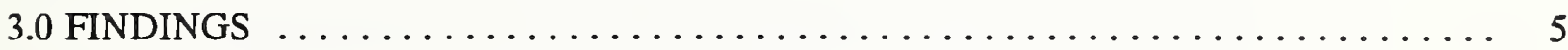

3.1 DESCRIPTION OF THE FIRE AREA $\ldots \ldots \ldots \ldots \ldots \ldots \ldots \ldots \ldots \ldots$

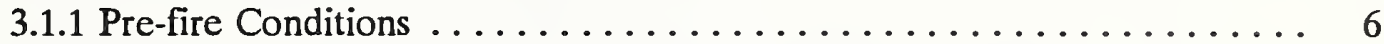

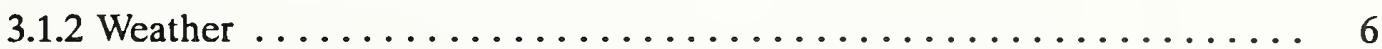

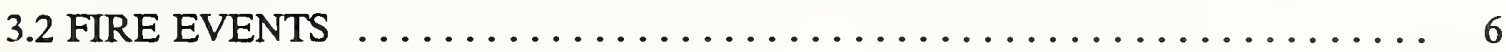

3.3 FIRE LOSSES $\ldots \ldots \ldots \ldots \ldots \ldots \ldots \ldots \ldots \ldots \ldots \ldots \ldots \ldots \ldots$

3.4 FIRE RESISTANCE OF BUILDINGS $\ldots \ldots \ldots \ldots \ldots \ldots \ldots \ldots \ldots$

3.4.1 Fire Characteristics of Roof Coverings ................ 8

3.4.2 Fire Resistance Of Wall Assemblies .................. 9

3.5 BUILDING REQUIREMENTS . . . . . . . . . . . . . . . . . 9

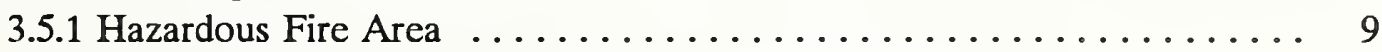

3.5.2 Model Codes . . . . . . . . . . . . . . . . . . . . . . . . 10

3.5.3 Requirements In Japan . . . . . . . . . . . . . . . . 10

3.6 WILDLAND/URBAN INTERFACE FIRE $\ldots \ldots \ldots \ldots \ldots \ldots \ldots \ldots \ldots \ldots$

3.7 ROLE AND FATE OF STRUCTURES . . . . . . . . . . . . . . . 12

3.7.1 Parkwoods Apartments . . . . . . . . . . . . . . . 13

3.7.2 Hiller Highlands Subdivision . . . . . . . . . . . . . . 13

4.0 CONCLUSIONS $\ldots \ldots \ldots \ldots \ldots \ldots \ldots \ldots \ldots \ldots \ldots \ldots \ldots \ldots \ldots \ldots \ldots \ldots$

4.1 THE OAKLAND HILLS FIRE $\ldots \ldots \ldots \ldots \ldots \ldots \ldots \ldots \ldots \ldots \ldots \ldots$

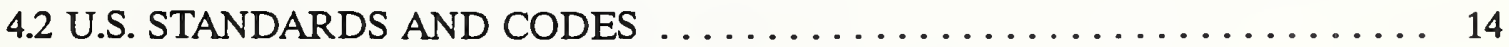

4.3 RELEVANCE TO MULTI-FAMILY WOOD FRAME HOUSING
CONSTRUCTION $\ldots \ldots \ldots \ldots \ldots \ldots \ldots \ldots \ldots \ldots \ldots \ldots \ldots \ldots \ldots \ldots$

5.0 RESEARCH RECOMMENDATIONS $\ldots \ldots \ldots \ldots \ldots \ldots \ldots \ldots \ldots \ldots \ldots$ 


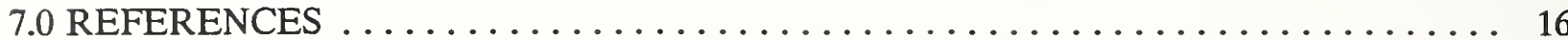




\section{LIST OF TABLES}

$\underline{\text { Page }}$

Table 1. Oakland International Airport Weather Records

\section{LIST OF FIGURES}

Figure 1. Portion of U.S. Geological Survey topographic map (1980) showing the area involved in the Oakland hills fire. Numbers indicate locations of major fire events as discussed in section 3.2.

Figure 2. Fire rekindles on hill side between Buckingham Blvd. and Grizzly Peak Blvd. (Image courtesy of KTVU News, Oakland, California, broadcast October 20, 1991).

Figure 3. Fire from burning vegetation enters area of Parkwoods Apartments. (Image courtesy of KTVU News, Oakland, California, broadcast October 20, 1991).

Figure 4. Aerial view of the Oakland and Berkeley hills on April 30, 1990. (Photograph from Pacific Aerial Surveys of Oakland, California).

Figure 5. Aerial view of Oakland and Berkeley hills on October 23, 1991 (Photograph from Pacific Aerial Surveys of Oakland, California).

Figure 6. Homes built amid vegetation west of the Oakland hills fire area.

Figure 7. Recent wildland/urban fires in the United States. (Chart by Paul Grabowicz and Dan Hubig, published in the Oakland Tribune, October 31, 1991).

Figure 8. Winds fan burning of homes and adjacent vegetation during the Oakland hills fire. (Image courtesy of KTVU News, Oakland, California, broadcast October 20, 1991).

Figure 9. Damage along Beechwood Drive near Glenbrook Drive (just south of Acacia Avenue in figure 1) at the periphery of the fire zone north of Mountain View Cemetery.

Figure 10. Buildings in the Parkwoods Apartments complex prior to the fire. (Photograph from Oakland Tribune files).

Figure 11. Burning roof and third floor apartment during Oakland hills fire. (Image courtesy of KTVU News, Oakland, California, broadcast October 20, 1991). 
Figure 12. Remains of one of the buildings in the Parkwoods Apartments after the Oakland hills fire.

Figure 13. Section of the Hiller Highlands subdivision prior to the Oakland hills fire. (Photograph by Richard Warwick published in the Oakland Tribune, October 27, 1991).

Figure 14. Section of the Hiller Highlands subdivision (also shown in figure 13) after the Oakland hills fire. (Photograph by Michael Macor, published in the Oakland Tribune, October 27, 1991).

Figure 15. Aerial view of Hiller Highlands subdivision after the Oakland hills fire. State Highway 24 which the fire spotted across is seen in the upper right. (Photograph by Gary Reyes, published in the Oakland Tribune, October 23, 1991). 


\title{
Preliminary Study of the 1991 Oakland Hills Fire and Its Relevance to Wood-Frame, Multi-Family Building Construction
}

\author{
Kenneth D. Steckler \\ David D. Evans \\ Jack E. Snell
}

\begin{abstract}
The purpose of this study was to establish the relevance, if any, of the Oakland hills wildland and suburban fire that occurred on October 20, 1991, to the design of multi-family wood-frame housing in the United States (U.S.) and Japan. A group of fire scientists and experts in building practices from both countries studied the fire through inspections of the site and meetings with local fire and building officials. The high wind speed, proximity of flammable vegetation to structures, and the flammability of exterior construction materials were factors in the spread of the fire. The use of wood framing members in the construction of multi-family housing did not influence significantly the rate of spread or extent of the fire. The severity and duration of the exposure, from fires ignited both outside and inside of buildings, resulted in total destruction of most structures within the fire area, regardless of the type of construction.
\end{abstract}

\subsection{INTRODUCTION}

On Sunday, October 20, 1991, Oakland, California experienced one of the worst single fire losses of its history, in fact it was one of the largest fire loss events in recent U.S. history. In less than 24 hours, 25 persons were killed including a police officer and a fire officer, and some 2889 dwellings were destroyed. The conflagration covered $7.2 \mathrm{~km}^{2}$ and was characteristic of an wildland/urban interface fire which spread into suburban housing developments. Strong winds, combined with unusual heat and drought, established conditions necessary for this major fire.

This report summarizes the results of a preliminary study of the Oakland hills fire undertaken by staff of the National Institute of Standards and Technology (NIST), Building and Fire Research Laboratory with funding from the U.S. Department of Agriculture's (USDA) Targeted Export Assistance Program. The study was conducted under subcontract from the National Forest Products Association (NFoPA) under a USDA agreement. The purpose of the study was to establish the relevance, if any, of this fire to the design practices for multi-family wood frame housing in the U.S. and Japan. Both nations have experienced urban and wildland/urban interface fires in the past.

Multi-family wood frame construction is widely accepted in the U.S., especially in earthquake prone areas. Three-story wood-frame construction is gaining acceptance in Japan. Both nations are concerned about the potential relevance of this fire to planned revisions to Japan's Building Standards Law. Both nations are committed to performance fire codes and consider fires like this one as tests of the thinking that goes into such codes and the adequacy of the technical bases for them. 
The collection of data in the field, analysis, and reporting of the preliminary results of this study were performed in one month in order to have the results and findings available at the time of the planned meeting of the joint U.S. and Japan Building Experts Committee meeting early in December, 1991. Due to the fact that this study was completed before the results of official local and state investigations became available, the analysis and conclusions presented herein should be viewed as preliminary and related only to the narrow objective stated above.

Access to the fire site and field visits with state and local officials were provided at the invitation and with the assistance of the Fire Marshal of the State of California and his regional representative. NIST is authorized by the Fire Prevention and Control Act of 1974, Public Law 93-498, to perform field investigations of fires relevant to its research activity and does so at the invitation of appropriate state and local authorities.

\subsection{APPROACH}

The work plan for this study was designed to provide a group of experts from the U.S. and Japan, which included individuals from both countries knowledgeable in fire science and building practices, the opportunity to inspect the fire area guided by local officials who were intimately familiar with local conditions prior to the fire and the fire events. This provided all parties with the best and most accurate information available one week after the fire. After gathering facts through multiple visits to the fire area, meetings were held with key fire and building officials, and research professionals in the region to obtain their thoughts on the fire events and perspective on the part played by building construction practices. A wrap-up meeting of the group was held, before leaving the Oakland area, to share observations and preliminary views about the relevance of the fire to construction of wood-frame multi-family housing in the U.S. and Japan.

NIST made arrangements for logistics support of the group's activities through the Office of the California State Fire Marshal. Chief Joe Garcia of the Coastal Regional Division provided thorough technical information about the fire events, and working facilities for team activities in the regional offices of the State Fire Marshal. He also made all arrangements for visits to local and state officials requested by the group, and escorted the group into areas of the fire site that were closed to the general public.

\subsection{PARTICIPATING U.S. AND JAPAN EXPERTS}

Members of the investigation team from NIST were Drs. Snell, Deputy Director; Evans, Head of the Fire Suppression Group; and Mr. Steckler of the Building and Fire Research Laboratory of NIST. Dr. Snell served as head of the U.S. team.

In California, the NIST team was joined by a delegation of fire and building officials from Japan led by Mr. Inoue of the Housing Bureau of the Ministry of Construction. This team included Professor Sugahara, Department of Architecture, Tokyo University; Dr. Hasemi, Head of the Fire Safety Section, Building Research Institute; Mr. Suzuki, Chief Architect, Misawa Homes Co., Ltd.; Mr. Yamamoto, Structures Section, Building Center of Japan; and Mr. Matsutani, the interpreter, of Berkeley, California.

The NIST team was assisted in fact finding by Mr. Klem, the National Fire Protection Association's (NFPA) lead fire investigator, who performed an extensive investigation of this fire for NFPA during 
the week prior to the arrival of the NIST team and Mr. Okawa, an official from the International Council of Building Officials (ICBO) -- one of the organizations in the U.S. responsible for the model codes used as the basis for building and fire codes in Oakland.

Representatives of the U.S. wood industry were present and participated in the investigation as follows: Mr. Tyree and Mr. Walker of the National Forest Products Association (NFoPA) and Mr. Bacca of the Western Wood Products Association accompanied the team on its visits Monday through Wednesday, and Mr. Caldwell, Director for Codes and Standards, NFoPA, participated in the scheduled events on Thursday and Friday up to but not including the final wrap-up session between U.S. and Japanese officials. These men were very helpful in providing technical information about building materials and construction practice.

\subsection{MAJOR ACTIVITIES}

\subsubsection{Visits To The Fire Site}

The combined American and Japanese team of experts had the opportunity to inspect the fire site several times during the week of October 28 through November 1, 1991. On October 29, all parts of the fire site were visited on a comprehensive all day review of the site and fire events led by Chief Garcia from the State Fire Marshal's Office. On the second visit, the following day, attention was concentrated on the area around the ignition site and the Hiller Highlands subdivision. Access to the Parkwoods Apartment complex, visited the previous day, was not possible as the area had been turned over to the owners. The third visit on October 31 and fourth on November 1 concentrated on the perimeter of the fire area in Rockridge and Lower Montclair. The perimeter area that contained both destroyed and undamaged structures was thought to provide the best opportunity to determine, if possible, information about fire ignition and spread mechanisms, and the relative resistance of different types of building construction to the fire.

\subsubsection{Meeting With The California State Fire Marshal}

California State Fire Marshal, Chief James McMullen, described the role of the state fire marshal's office, the operation of the incident command system for management of disasters such as this fire, and the efforts undertaken by his office relative to this fire and similar fires in the past. Specifically, he noted that three separate investigations are underway through his office as a result of agreement between state and local authorities, as follows:

Investigation of the conditions that led to such a rapidly developing fire.

Investigation of the cause and origin of this fire.

Evaluation of the fire fighting procedures employed.

Chief McMullen noted that previous attempts to introduce statewide legislation to reduce the risks of such fires have been only partially successful. For example, in 1988, a measure applicable to state regulated areas, primarily non-incorporated areas and state lands, was passed which requires minimum fire characteristics of Class $\mathrm{C}$ roofs* (thus preventing use of untreated wood shingles) in all new construction, and requires maintenance of specified brush clearances from buildings. This measure

*Fire rating of roof covering is discussed in section 3.4.1. 
applies to about one third of the land in California, but does not include this fire area since it is within the cities of Oakland and Berkeley. Earlier efforts to ban untreated wood shake roofing materials statewide were not successful. Other relatively recent statewide proposals that would have required at least Class $\mathrm{C}$ roofing have not survived through the state legislature.

\subsubsection{Meeting With Researchers At The University Of California, Berkeley}

The delegation met with two professors at the University of California, Berkeley who had prepared materials for presentation at a public meeting about the fire scheduled for the next week. Professor Brady Williamson described the current test method for roof coverings in the U.S. is ASTM E $108[1]^{* *}$ and noted that no such test is available for exterior siding materials. Professor Patrick Pagni mentioned that an ordinance passed in Berkeley following the similarly disastrous fire of 1923 was rescinded within 6 months of its enactment. Professor Pagni also described the role of weather [2], the eucalyptus trees, and natural vegetation in this and similar fires in the past. In short, Professor Pagni noted that such fires are predictably recurrent, and proposed that a series of steps be taken to mitigate their consequences as follows:

1. Research to clarify mechanisms of fire growth and spread and to design appropriate interdictions.

2. A new building code specific to the wildland/urban interface:

a. $\quad$ narrower selection of materials,

b. $\quad$ strict control and inspection of building sites and vegetation thereon,

c. guaranteed water supplies for the fire service and residential sprinklers.

3. Additional taxation exclusively directed to maintaining the fire service.

There was some discussion of the technical basis for and possible technical approaches for carrying out the first two of these proposals.

\subsubsection{Meeting With Oakland Building Official}

The meeting with the building official for the city of Oakland, Raymond Derania, Manager of the inspection services of the Development Services Department, was most useful since his office is responsible for assessing the condition of the housing affected by the fire. Mr. Derania described actions taken by his office to respond to the fire, to set up a one-stop emergency assistance center for fire victims, to inventory damage done to properties affected by the fire, to initiate actions to prevent further risk to the residents of the area, and to plan for reconstruction. He also described the codes and standards in effect in Oakland, particularly those affecting townhouse and apartment structures. However, the specific requirements in force at the time of construction of each of the structures destroyed in the fire could not be determined at this time. His office is compiling a detailed listing of pertinent information on each of the buildings destroyed or damaged by the fire. None of the buildings gutted by the fire are repairable. Mr. Derania's office has condemned all remaining chimneys and foundations. Also, he agreed to provide what detailed information they have

\footnotetext{
**Numbers within brackets indicate references listed in Section 7.0
} 
on the townhouse and apartment structures destroyed in the fire, the Parkwoods Apartments, and the townhouses and condominiums in the Hiller Highlands subdivision.

\subsubsection{Wrap-up Meeting}

This meeting was arranged by NIST to bring all parties together before they left the area to review information acquired and to share initial impressions about what had been seen during the past few days. Those attending the wrap-up session included Dr. Snell, and Mr. Steckler and Mr. Klem from the U.S. and Mr. Inoue, Professor Sugahara, Dr. Hasemi, Mr. Suzuki and Mr. Yamamoto from Japan and Mr. Matsutani, the interpreter.

The group considered the relevance and implications of what had been seen and heard to the U.S. and Japan, including specifically, multi-family wood-frame housing. The group considered the recommendations suggested by Professor Pagni, and generally agreed that special consideration needs to be given to the flammability of the exterior shell of buildings -- roofing and siding -- in such high risk fire zones as the wildland/urban interface.

The building environment interrelationship was discussed. The many variations in buildings and vegetation need to be considered in deciding what combinations are safe from fire.

Fire retardant materials were discussed. In the past, such treatments became ineffective after exposure to weather but now new systems are available. The Japanese mentioned an innovative treatment that turns wood products into something like "petrified" wood which is essentially noncombustible. Apparently, this material is still quite expensive and currently its use is limited to fire doors.

It was felt important whether talking about the U.S. or Japan to understand the potential risks to a particular building on a specific building site. In the past, codes have tended to treat things that are very different as if they are the same. In some situations, this means excess cost, in others excess risk. It was generally agreed that increased built-in fire protection -- both active and passive -- are important. The fire hazards of uncontrolled combustible building contents and the difficulties of maintaining fire fighting capabilities both make prevention and built-in protection important.

Regarding three story multi-family wood frame construction in Japan, the criteria that had been mentioned prior to the Oakland hills fire were:

1. Life safety of the occupants of a building from fire within the building,

2. potential hazard of spread of fire from fire within a building to other buildings.

In view of the Oakland hills fire, it was felt that explicit attention also should be given to the threat of fires of external origin.

\subsection{FINDINGS}

The following paragraphs represent the principal findings of the NIST team based on the foregoing activities, including observations at the fire site and review of the relevant literature. 


\subsection{DESCRIPTION OF THE FIRE AREA}

The area in which the fire occurred is a suburban residential community located in a northern section of the City of Oakland, California and southeastern section of the City of Berkeley, California in the area surrounding the intersection of state highway numbers 24 and 13 , located at approximately $38^{\circ}$ $51^{\prime}$ north latitude and $122^{\circ} 14^{\prime}$ west longitude.

This area has steep hills, with some, as the hill side on which the fire started, having $58 \%$ grades (30 degree slopes). Streets are paved but often narrow with numerous sharp curves. In general, moist air (fog) from the ocean produces abundant growth on the west slopes of the Oakland and Berkeley hills. Homes are built on the hill slopes and often surrounded by ornamental bushes, plants, and eucalyptus and pine trees.

A wide variety of structures were built within the fire area between 1921 and 1991. Most appeared to be wood frame with stucco, wood panel, wood shingles, or brick veneer siding. Roofs varied as well, including asphalt shingles, ceramic tile, and wood shake. Detailed information on each of the buildings destroyed or damaged by the fire is being compiled by the Oakland Development Services Department, but was not completed at the time of this writing.

\subsubsection{Pre-fire Conditions}

Vegetation was extremely dry due to the five-years of drought. Many eucalyptus trees bore dead leaves, twigs, and limbs as a result of a 4-day frost in December 1990. Dry wild grass was abundant owing to the "March Miracle" (46 mm of rainfall) (1 7/8 inch) followed by the dry summer. For two weeks prior to the fire, the humidity was low and the winds were warm and sporadic.

\subsubsection{Weather}

The temperature, humidity (wet bulb temperature), wind speed, and wind direction for day of the fire, October 20, 1991, are available from records kept at the Oakland International Airport (see table 1). Although these records give some indication of weather in the area, it should be noted that, especially with respect to the wind, changes in elevation and topography can have a substantial effect. The airport is located near sea level, approximately $15 \mathrm{~km}$ southeast of the location $330 \mathrm{~m}$ above sea level in the Oakland hills where the fire started. In this regard, it is interesting to note, that even though in the fire area there were many reports of gusty and swirling winds during the fire, no records of wind gusts or erratic wind directions were made at the airport. As recorded in table 1, wind directions were predominately from the north, northeast, and east throughout the day, but temperature and wind speed increased, and relative humidity decreased, just prior to the reported rekindling of the fire. Air temperatures reached $33^{\circ} \mathrm{C}\left(92^{\circ} \mathrm{F}\right)$ at 16 percent relative humidity.

\subsection{FIRE EVENTS}

The fire of Sunday October 20 started on an approximate 58\% grade (30-degree slope) near Buckingham Boulevard north of the Caldecott Tunnel (see figure 1). It grew out of the aftermath of a $2 \times 10^{4} \mathrm{~m}^{2}$ (5 acre) brush fire that occurred in the same area the day before (when there was no wind) and was easily controlled. The following timeline of the fire events was compiled from information published in the Oakland Tribune Newspaper and from information given by Chief Joe Garcia of the California State Fire Marshal's Office during the tours of the fire site. Numbers given 
refer to the approximate locations indicated on the map of the Oakland-Berkeley hills area shown in figure 1.

1. Firefighters were on the scene Sunday looking for hot spots from Saturday's fire when winds rekindled the fire at about 1045 hours, see figure 2. Initially, the fire spread up the slope toward Grizzly Peak Boulevard.

2. Firefighters were moved to the high ground to fight the on-coming fire from above. At 1100 hours firefighters reported that the fire was beginning to spread eastward from the area of origin.

3. The wind shifted to the south at 1110 hours and the fire began spreading down the slope toward the Parkwoods Apartments located near the entrance to the Caldecott Tunnel. This hot, dry, locally erratic Santa-Ana type wind averaged about $9 \mathrm{~m} / \mathrm{s}$ $\left(20 \mathrm{mph}\right.$ ) with gusts from 16 to $22 \mathrm{~m} / \mathrm{s}(35$ to $50 \mathrm{mph})$. At 1130 hours, $4 \times 10^{5} \mathrm{~m}^{2}$ (100 acres) were burning. The fire entered the area of the Parkwoods Apartments at about 1140 hours, see figure 3 .

4. By 1145 hours fire brands were falling on the Charring Cross Road area which is located southwest of the ignition point. This arm of the fire spread through the Hiller Highlands subdivision in 30 to 40 minutes.

5. By 1215 hours the fire spotted across Route 24 and started fires along Buena Vista Place.

6. About 1400 hours the fire jumped Route 24 into the area northeast of Lake Temescal.

7. The northwest "edge" of the fire zone approached the Claremont Hotel (adjacent to the Berkeley Tennis Club) between 1400 hours and 1600 hours.

8. The southwest edge was north of Mountain View Cemetery at 2000 hours.

9. Early that evening the winds subsided and in places changed direction to blow back over areas already burned. A perimeter was drawn around the fire by 0400 hours Monday, October 21. The fire was declared "contained" on Tuesday afternoon and "under control" at 0800 hours Wednesday, October 23. 


\subsection{FIRE LOSSES}

Losses due to fire are summarized as follows [3]:

FATALITIES

INJURIES

AREA INVOLVED

RESIDENCES DESTROYED

Single Family

Apartments and Condominiums

Rental Units

OTHER STRUCTURES

(e.g. storage sheds, and detached garages)

Destroyed

Minor Damage

Affected (utilities)

BUSINESSES

Destroyed

Affected

ESTIMATED COST
25

150

$7.2 \mathrm{~km}^{2}(1780$ acres $)$

2889

(437)

(3)

58

1

1

\$1.5 Billion

The majority of the fatalities (20 out of 25 ) occurred north of State Highway Route 24 in the areas that were overrun by the fire during the first 60 to 90 minutes. These included the areas of the Parkwoods Apartments and Hiller Highlands subdivision. The extremely rapid spread of the fire, dense smoke, and narrow roads all contributed to the large loss of life in these areas.

Figure 4 shows an aerial photograph of Oakland and Berkeley hills on April 30, 1990 about 18 months prior to the fire. Figure 5 shows the same area on October 23, 1991 after the conflagration. Virtually all of the structures within the large central area of the fire zone were destroyed. Along the perimeter of the fire zone there are totally destroyed, partially damaged, and apparently untouched structures intermixed. It is believed that intervention by the fire department saved most of these "untouched" homes.

\subsection{FIRE RESISTANCE OF BUILDINGS}

\subsubsection{Fire Characteristics Of Roof Coverings}

The standard classification method for the fire characteristics of roof covering in the U.S. is ASTM E 108 [1] which specifies that the roof covering material be subjected to four different fire tests. The four fire tests evaluate the resistance to intermittent-flame impingement on the roof, to flame spread from a continuous gas flame source, to burning wood brands placed on the roof, and resistance to the production of flying brands. The tests are intended to measure the relative fire characteristics 
of roof coverings under simulated fire originating outside the building. Roof covering materials are classified into four groups: A, B, C, and nonrated.

Roof coverings rated as class $\mathrm{A}, \mathrm{B}$, and $\mathrm{C}$ are intended to satisfy the following [1]:

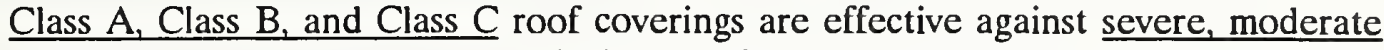
and light fire exposures respectively. Under such exposures, roof coverings of Class A. Class B, and Class C, afford a high, moderate, and light degree, respectively, of fire protection to the roof deck, do not slip from position, and do not present a flying brand hazard.

It is noted in the standard [1] that:

The tests define the performance of a roof-covering material under specific test fire conditions. They do not provide information on the performance of roof-covering materials under other conditions or in actual fire situations.

Those roof coverings not satisfying the requirements of the above test method are nonrated. Some built-up and untreated wood shingles and shakes roof coverings are nonrated. The fire hazard of untreated wood shingles has been recognized for many years, yet major loss fires involving these materials are recurrent $[4,5,6]$.

\subsubsection{Fire Resistance Of Wall Assemblies}

In the United States, the fire resistance of wall assemblies is evaluated using the ASTM E 119, Standard Test Method for Fire Tests of Building Construction and Materials [7]. Assemblies are classified according to the time satisfactory resistance to a specified time-temperature exposure on one surface is maintained. A commonly specified rating is 1-hour fire resistive assemblies.

\subsection{BUILDING REQUIREMENTS}

At the time of this writing, records about the construction of wood-frame multi-family buildings in the fire area, such as the Parkwoods Apartments, were being organized by local authorities and were not available for this analysis. Thus, only general comments about minimum requirements specified in the local regulations at the time of construction and those presently enforced are included in this report.

\subsubsection{Hazardous Fire Area}

In California, some areas are designated as hazardous fire areas in which special fire resistive and fire protection measures are required. A hazardous fire area is defined by the Uniform Fire Code [8] as:

... any land which is covered with grass, grain, brush or forest, whether privately or publicly owned, which is so situated or is of such inaccessible location that a fire originating upon such land would present an abnormally difficult job of suppression or would result in great and unusual damage through fire or resulting erosion. 
This definition is used by local authorities in both Oakland and Berkeley to determine if areas within the jurisdictions should be classified as Hazardous Fire Areas. In practice, areas in which buildings can be accessed by paved roads are considered not to present abnormally difficult fire suppression conditions for the fire service and therefore are not considered Hazardous Fire Areas. In the Oakland and Berkeley hills area all residences were accessible by paved roads and therefore none of the area was designated a Hazardous Fire Area.

\subsubsection{Model Codes}

Requirements for the fire resistance and fire protection of buildings are established and enforced only by state and local community authorities. There is no national building or fire code in the United States. Several organization within the U.S. provide model codes which are used by state and local authorities for establishing local regulations. Three organizations within the U.S. provide model building codes which are used by local authorities for establishing local regulations. The model building code organizations do not directly enforce building requirements. Until adopted by states or local jurisdictions, the model building and fire codes published by each organization are not regulations. The organizations which publish model building and fire codes and standards are:

1. The Southern Building Code Congress International (SBCCI), Birmingham, Alabama publishes the Standard Building Codes. These codes are primarily adopted by states in the Southern region of the United States.

2. The Building Officials and Code Administrators International (BOCA), Country Club Hills, Illinois publishes the National Building Codes. These codes have been adopted by several states in the Northeastern and Midwestern regions of the United States.

3. The International Conference of Building Officials (ICBO), Whittier, California publishes the Uniform Building Codes. These codes have been adopted by states in the Western, Midwestern and Pacific Rim regions.

4. The National Fire Protection Association (NFPA), Quincy, Massachusetts publishes the Code for Safety to Life from Fire in Buildings and Structures. This fire safety code is used widely in the U.S. and also by some agencies of the U.S. government.

Often a local jurisdiction selects one of the model codes as the basis for establishing its own regulations. The requirements published in the model code may be modified by local authorities in the process of establishing local regulations for the community. At present, both the City of Oakland and the City of Berkeley use the 1988 edition of the Uniform Building Code [9] as the basis for local regulations.

\subsubsection{Requirements In Japan}

Proposed changes to the Japanese Building Standard Law (BSL), which are now in draft form, would allow the construction of 3 -story wood-frame multi-family dwellings with less than $1000 \mathrm{~m}^{2}$ floor area in 1991, and less than $3000 \mathrm{~m}^{2}$ during and after 1993 in areas other than the two most restrictive fire zones. The fire resistance of the buildings load-bearing walls, separation walls, and floors (ceilings) will have to be rated at a minimum of 1 -hour as evaluated in standardized fire tests. The roofs of large wooden buildings must be made of non-combustible material, while external walls, and other 
areas liable to catch fire must be of "fire preventive construction" (construction which passes JIS A 1301 [10]). The 3-story wood-frame structure which is about to be tested at the Building Research Institute in Japan meets the above requirements.

\subsection{WILDLAND/URBAN INTERFACE FIRE}

The Oakland hills fire was literally the textbook example of the wildland/urban fire. The recently published textbook Wildland/Urban Interface Fire Protection: A National Problem with Local Solutions [11], produced by the National Fire Academy, part of the U.S. Federal Emergency Management Agency (FEMA), for its course on the subject begins with a description the interface fire. It is reproduced here because of the agreement with all but the details of the fire being studied:

The morning weather report predicts another hot, dry day. For several weeks now there has been no precipitation, and the cumulative rainfall is far short of the annual average. A strong, easterly wind moves across dried grass and shrubs in the area developments, and surrounding wildland vegetation is brittle -- dried to tinder from prolonged drought. At mid-morning, a call comes into the local fire service: Smoke sighted in the forest to the east of a major housing development.

By the time the first fire service units arrive on the scene, the fire is already out of control. Flames reach 150 feet into the air, and burning embers carried by the strong winds are starting new fires one-half mile in advance of the fire front. The magnitude of the fire quickly outstrips local fire service resources, and additional units are called in. But the fire is moving quickly -- and some difficult decisions must be made. With insufficient resources, the fire service recognizes that it will not be able to protect all the houses in the line of the approaching fire.

In the community three miles away to the east, panic has set in. Houses here are perched on the top of a slope and nestled in the forest. Smoke from the approaching fire has darkened the sky, and cars are using their headlights on the already clogged twolane access road. The local police have loudspeakers telling residents to evacuate the area. With its limited resources, the fire service cannot protect these houses from the approaching fire. Lack of access to the area, homes too close to trees, flammable building materials, and the sheer size of the approaching fire .- a number of elements prohibit the fire service from protecting this community.

Frantic homeowners are torn between the desire to stay and try to protect their homes and the fear of the approaching fire. Residents pack what they can into the trunks of cars and take a final backward look at their homes, their dreams. When they try to return to their homes, most of these families will find only ashes. The cost of these fires will be enormous...

It is obvious from the above passage that the wildland/urban fire event is anticipated to occur again and again as people choose to establish homes amid vegetation, such as pine and eucalyptus trees, tall grasses, and chaparral throughout the United States. Photographs provide some indication of the vegetation that existed in the area around homes in the Oakland hills. Figure 6 shows homes built on slopes amid vegetation immediately to the west of the fire area. It is easy to see, that a fire 
similar to the Oakland hills fire could occur again. In fact, in the United States an average of four hundred homes per year from 1986 to 1989 were destroyed in wildland/urban fire, see figure 7.

By definition, the wildland/urban interface fire involves both burning natural vegetation and manmade structures. Fire spread through natural vegetation has been studied for application in forest and range fire fighting. As a result of this research, analytical methods have been developed to predict the spread of fire through many characteristic wildland vegetation types under varying temperature, humidity, fuel moisture content and wind speeds [12]. No similar technology yet exists for wildland/urban interface or suburban areas.

The benefits of keeping highly combustible brush away from housing has been clearly demonstrated. For example, an economic analysis of the fire protection alternatives for the Santa Monica Mountains of southern California completed in 1975 found from a societal viewpoint that maintenance of brush clearances and conversion of untreated wood shingle roofs represented the most cost effective means of protection from wildfire [13].

\subsection{ROLE AND FATE OF STRUCTURES}

In an wildland/urban fire and in particular the Oakland hills fire being studied here, an interesting question arises, "What was the role played by the structures in the spread and intensity of the fire?" In this fire, both flammable vegetation and flammable exterior construction provided a means for the fire spread. Spotting of the fire to initiate new areas of burning also was a factor.

Close spacing of houses, in some areas, with and without intervening vegetation led to both direct vegetation-to-structure and structure-to-structure fire spread through flame impingement, wind-blown flaming debris, and radiation during the conflagration, see figure 8. Exterior walls were exposed to fires on both sides as interiors were ignited by radiation or flames entering through broken windows.

A roof is usually the most vulnerable part of a building in an wildland/urban fire since it provides a surface to catch and hold airborne brands. Consequently, the fire characteristics of the roof can often determine whether a structure is destroyed or not in situations where there is little or late intervention. Also, if the roof produces burning brands, it can have a significant effect on the overall spread rate of the fire.

In the Oakland hills fire, the degree to which wood framing contributed to the spread of the overall fire zone was insignificant compared to the role of the abundant easily ignited combustibles (dry vegetation, combustible roofing and siding) and burning brands. Flaming brands were produced by brush, trees, and wood shingles.

Protected combustibles such as the wood framing present in most of the structures only contribute to the fire in the later stages when the fire resistance of protective materials had been exceeded by the duration and intensity of the fire outside and inside the structure. Failure of the wood framing members led to structural collapse but only after a long and severe fire exposure exceeding conditions that could be survived by occupants. The burning and failure of wood framing members, being after passage of the fire front, made no significant contribution to the spread of the fire during its rapid growth period. Wood framing did contribute to the intensity and duration, and possibly to the subsequent local spread of fire; e.g., between closely spaced buildings. 
The area involved in the fire contained a wide variety of construction types -- combustible, fire resistive, and non-combustible. Driving through the interior of the fire area it appeared that most structures were destroyed. At the periphery of the fire zone nearly all homes on one side of a street were totally destroyed. On the other side of that street many remained, see figure 9 . Beyond the undamaged homes there were some partially destroyed homes. It appeared that flaming brands may have ignited combustible roofs and/or vegetation near the partially destroyed homes.

Factors such as spacing between structures, vegetation clearance distances, and noncombustible roofing and siding played some role in determining which buildings survived. These factors also strongly influenced decisions by firefighters about intervention. At the periphery, fire fighting strategy was to direct limited resources at structures which appeared to have the best chances of survival. However, even at the periphery of the fire zone, it appeared that the presence of a noncombustible exterior did not guarantee the survival of a home.

\subsubsection{Parkwoods Apartments}

Although the predominate type of housing involved in the fire was single family dwellings, a number of three-story apartment buildings were destroyed. Special attention is directed at the performance and fate of these structures in the fire. This is difficult because of the lack of definitive information about the construction of the buildings and limited information about the fire exposures.

The apartment buildings were constructed before 1980. Figure 10 shows two of the three-story apartment buildings before the fire. Based on ICBO codes, published in the early 1970's, the threestory wood-frame apartment building structures would have been required to have one-hour rated construction throughout. As these codes permitted ordinary roofing, it is possible that the built-up roof covering was nonrated. The flat roof apartment buildings, which were built in a valley surrounded on three sides with steep hills in which the fire started, were probably subjected to repeated landing of fire brands which caused multiple ignitions of the roof. The presence of numerous eucalyptus tree fragments observed throughout the fire zone and reports of others having landed as far away as the other side of San Francisco bay, indicate that the eucalyptus trees were a probable source of flaming brands that influenced the spread of the fire. Figure 11 shows burning on the roof and third story apartment in one of the Parkwoods Apartment buildings during the Oakland hills fire.

The fire destroyed every building in the apartment complex. Figure 12 shows the remains of one building. The assumed one-hour rating for the construction was certainly exceeded by the combined effects of exterior and interior fires leading to collapse of the three-story wood-frame construction.

\subsubsection{Hiller Highlands Subdivision}

The fire began in an area that was on the edge of the developed land on the west side of Grizzly Peak Boulevard. Housing in that area is relatively sparse, compared to the high density attached housing found in the Hiller Highlands subdivision. Figure 13 shows a section of the Hiller Highlands subdivision before the fire. Dwellings are closely spaced or attached to one another. Often vegetation is found throughout the open areas and in some cases in contact with the buildings. The fire approached the development from the other side of the hill shown in the picture (figure 13). The fire moved through the community in less than one hour, reducing the development to the rubble and ashes seen in figures 14 and 15 . The burning of this housing development was not 
characteristic of the wildland/urban interface fire that began on the other side of the ridge. The conflagration in this typical high density suburban development was the result of a developed wildland-like fire moving through a community that contained more housing than vegetation -- more urban than wildland.

\subsection{CONCLUSIONS}

\subsection{THE OAKLAND HILLS FIRE}

1. The Oakland-Berkeley hills fire began as a brush fire in an wildland/urban interface area and then progressed to a suburban conflagration before the winds subsided and it was brought under control.

2. Critical contributing factors to the extent of this fire were the drought conditions, the high wind speeds, low humidity, dense vegetation close to dwellings, and the flammability and branding characteristics of the vegetation and of some of the materials used for exterior finish -- roofing and siding -- of the housing.

3. In the interior of the fire area most structures were destroyed.

4. Even at the periphery of the fire the presence of a non-combustible exterior did not guarantee the survival of the structure.

5. Little can be said about buildings that survived, because there is no detailed record of the level, timing or even presence of suppression efforts by fire fighters or homeowners which could have been a determining factor, especially as the intensity of the winds diminished and the spread of fire was stopped.

6. The principal mechanisms of fire spread were wind-aided flame impingement on combustibles and wind and gust driven burning brands igniting either wildland brush or landscaping surrounding most of the buildings which burned, or the buildings themselves. Additionally, in areas where building separations were small, direct house-to-house flame radiation may have contributed to the intensity and spread of the fire.

\subsection{U.S. STANDARDS AND CODES}

1. There is no test method specifically designed to evaluate the performance of exterior siding materials to wind-driven flame impingement or radiation exposure. Current requirements for a one hour rating in the ASTM E 119 test do not address ignition of, flamespread on, or brands produced by exterior siding. The role played by combustible siding in wildland/urban fires needs to be evaluated. If needed, test methods can be developed and applied.

2. Building codes in force in Oakland and Berkeley, and model building and fire codes make no distinction for housing in wildland/urban interface zones or other similarly high fire risk locations.

\subsection{RELEVANCE TO MULTI-FAMILY WOOD FRAME HOUSING CONSTRUCTION}

1. There is no evidence that the wood-frame construction of the many buildings consumed in this fire had a significant impact on the overall rate of spread or extent of the fire. By the time there had 
been sufficient damage to a building to expose and involve the framing members of a house, the fire front was well beyond that building. The impact of the presence of wood framing is felt only after the fire resistance of the wall and roof finishings are overcome so the contribution is to the total burning intensity of the fire and the ultimate collapse of the structure. All of the buildings gutted by the fire, regardless of materials of construction, were condemned. Those few buildings within the fire zone that were only partially damaged include a number of wood frame houses.

2. The more fire resistant the exterior shell of wood frame buildings, the longer it will take for fire to involve the structural members. Thus, the ignition, flame spread, and fire resistance of the exterior shell -- roof and siding -- of housing in such high risk areas are important factors.

\subsection{RESEARCH RECOMMENDATIONS}

1. Research is needed to establish appropriate performance requirements for roof and exterior siding systems subject to potential external fire exposures from burning brands, wind-driven flame impingement, and direct radiation.

2. Research is needed to establish the contribution of collapse of a burning building and subsequent exposure of previously unburned fuels -- combustible interior contents, finishes, and/or framing -- to the spread of urban fire.

3. Research is needed to integrate existing building and wildland fire growth models, and associated fire science and data, into practicable tools: to predict and help mitigate the consequences of wildland/urban fires; to use for the identification and analysis of conditions necessary for urban conflagrations; and, to assess the effectiveness of alternate means for preventing or controlling such fires.

4. Research is needed to explore the potential effectiveness of alternative technologies for early suppression of wildland/urban and urban fires and for minimizing the rate of development and extent of such fires.

5. Research is needed to adapt existing computer fire models of multiple large fires to include local meteorology and terrain to replicate and better understand the interaction of winds, terrain, and flames which caused the fire to move so rapidly down the hills and through the housing developments of Oakland during this fire.

\subsection{ACKNOWLEDGEMENTS}

The team could not have completed this study without the generous support and assistance of the California State Fire Marshal, Chief James McMullen and his highly capable staff. We are especially appreciative of the selfless efforts of Chief Joe Garcia in sharing his views with the team, guiding the team through the fire scene and for -coordinating local arrangements for the various meetings conducted by the team. Also, the generous assistance provided by Raymond Derania of the Oakland Development Services Department, by Professors Patrick Pagni and Brady Williamson of the University of California at Berkeley, as well as the help provided by the NFPA and its highly competent representative, Tom Klem, and similar assistance provided by ICBO in the persons of Rick Okawa and John Traw were greatly appreciated. 
The authors appreciate the able assistance of Nora Jason and Jay McElroy of the Building and Fire Research Laboratory who helped compile the resource literature, reference data, photographs, etc.; and Harold Nelson, Richard Gann, Robert Levine and W. Douglas Walton who reviewed the text.

\subsection{REFERENCES}

1. ASTM E 108, Standard Test Methods for Fire Tests of Roof Coverings, ASTM Fire Test Standards, Third Edition, American Society for Testing and Materials, Philadelphia, PA, pp. 503-509 (1990).

2. Monteverdi, John P., The Santa Ana Weather Type and Extreme Fire Hazard in the Oakland-Berkeley Hills, Weatherwise, pp. 118-121, June 1973.

3. Survey conducted by the California Department of Forestry for the Office of Emergency Services (1991).

4. Wilson, Rexford, The Los Angeles Conflagration of 1961 The Devil Wind and Wood Shingles, National Fire Protection Association Quarterly, Quincy, MA, January 1962.

5. Bugbee, Percy, Men Against Fire -- The Story of the National Fire Protection Association 1896-1971, National Fire Protection Association, Quincy, MA (1971).

6. Black Tiger Fire Case Study, National Fire Protection Association, Quincy, MA, July 1989.

7. ASTM E 119, Standard Test Methods for Fire Tests of Building Construction and Materials, ASTM Fire Test Standards, Third Edition, American Society for Testing and Materials, Philadelphia, PA, pp. 514-534 (1990).

8. Uniform Fire Code, 1988 Edition, International Conference of Building Code Officials, Whittier, California (1988).

9. Uniform Building Code 1988 Edition, International Conference of Building Code Officials, Whittier, California (1988).

10. Japanese Industrial Standard, Method of Fire Test of Wooden Structural Parts of Buildings, JIS A 1301-1975, Japanese Standards Association, Tokyo, Japan (1975).

11. Wildland/Urban Interface Fire Protection: A National Problem with Local Solutions, U.S. Fire Academy, Emmitsburg, MD, Chapter 1, pp. 2-3 (1989).

12. Rothermel, Richard C., How to Predict the Spread and Intensity of Forest and Range Fires, General Technical Report INT-143, Intermountain Forest and Range Experiment Station, Ogden, UT, U.S. Department of Agriculture (1983).

13. North, Warner D., Offensend, Fred L., and Smart, Charles N., Planning Wildfire Protection for the Santa Monica Mountains -- An Economic Analysis of Alternatives, Fire Journal, Vol. 69 , No. 1, pp. 69-78 (1975). 
Table 1

Oakland International Airport Weather Records, October 20, 1991

\begin{tabular}{|c|c|c|c|c|}
\hline $\begin{array}{l}\text { Local Time } \\
\text { (24-Hour } \\
\text { Clock) }\end{array}$ & $\begin{array}{l}\text { Temperature } \\
{ }^{\circ} \mathrm{C}\left({ }^{\circ} \mathrm{F}\right)\end{array}$ & $\begin{array}{l}\text { Relative Humidity } \\
\text { (percent) }\end{array}$ & $\begin{array}{l}\text { Wind Speed } \\
\mathrm{m} / \mathrm{s}(\mathrm{mph})\end{array}$ & $\begin{array}{l}\text { Wind Direction } \\
\text { (Deg. from true } \\
\text { North) }\end{array}$ \\
\hline 0045 & $13(56)$ & 71 & $3(6)$ & 340 \\
\hline 0145 & $15(59)$ & 69 & $0(0)$ & $\ldots$ \\
\hline 0245 & $14(58)$ & 69 & $2(5)$ & 50 \\
\hline 0345 & $13(56)$ & 69 & $0(0)$ & --. \\
\hline 0445 & $16(60)$ & 69 & $2(5)$ & 130 \\
\hline 0548 & $13(56)$ & 70 & $0(0)$ & $\ldots$ \\
\hline 0645 & $13(56)$ & 71 & $3(6)$ & 40 \\
\hline 0745 & $17(63)$ & 65 & $0(0)$ & -- \\
\hline 0845 & $21(70)$ & 70 & $3(6)$ & 230 \\
\hline 0945 & $28(83)$ & 32 & $6(14)$ & 20 \\
\hline $1045^{*}$ & $31(88)$ & 17 & $10(23)$ & 40 \\
\hline 1145 & $32(90)$ & 17 & $10(23)$ & 40 \\
\hline 1245 & $33(91)$ & 16 & $10(23)$ & 40 \\
\hline 1345 & $33(92)$ & 16 & $6(14)$ & 40 \\
\hline 0445 & $33(92)$ & 16 & $8(17)$ & 360 \\
\hline 1545 & $33(91)$ & 16 & $8(17)$ & 360 \\
\hline 1645 & $32(89)$ & 17 & $5(12)$ & 40 \\
\hline 1745 & $29(85)$ & 16 & $3(6)$ & 50 \\
\hline 1855 & $26(78)$ & 37 & $3(6)$ & 160 \\
\hline 1945 & $23(74)$ & 44 & $0(0)$ & --. \\
\hline 2045 & $21(70)$ & 16 & $3(6)$ & 20 \\
\hline 2145 & $21(69)$ & 52 & $2(5)$ & 90 \\
\hline 2245 & $19(66)$ & 45 & $2(5)$ & 20 \\
\hline 2345 & $17(63)$ & 48 & $0(0)$ & --- \\
\hline
\end{tabular}

*Although sky and ceiling were listed as CLR (Clear: Less than 0.1 sky cover) in remarks it was noted that visibility was lower to the East [towards the Oakland hills].

**Indicates no identified wind direction for nominally zero wind speed. 



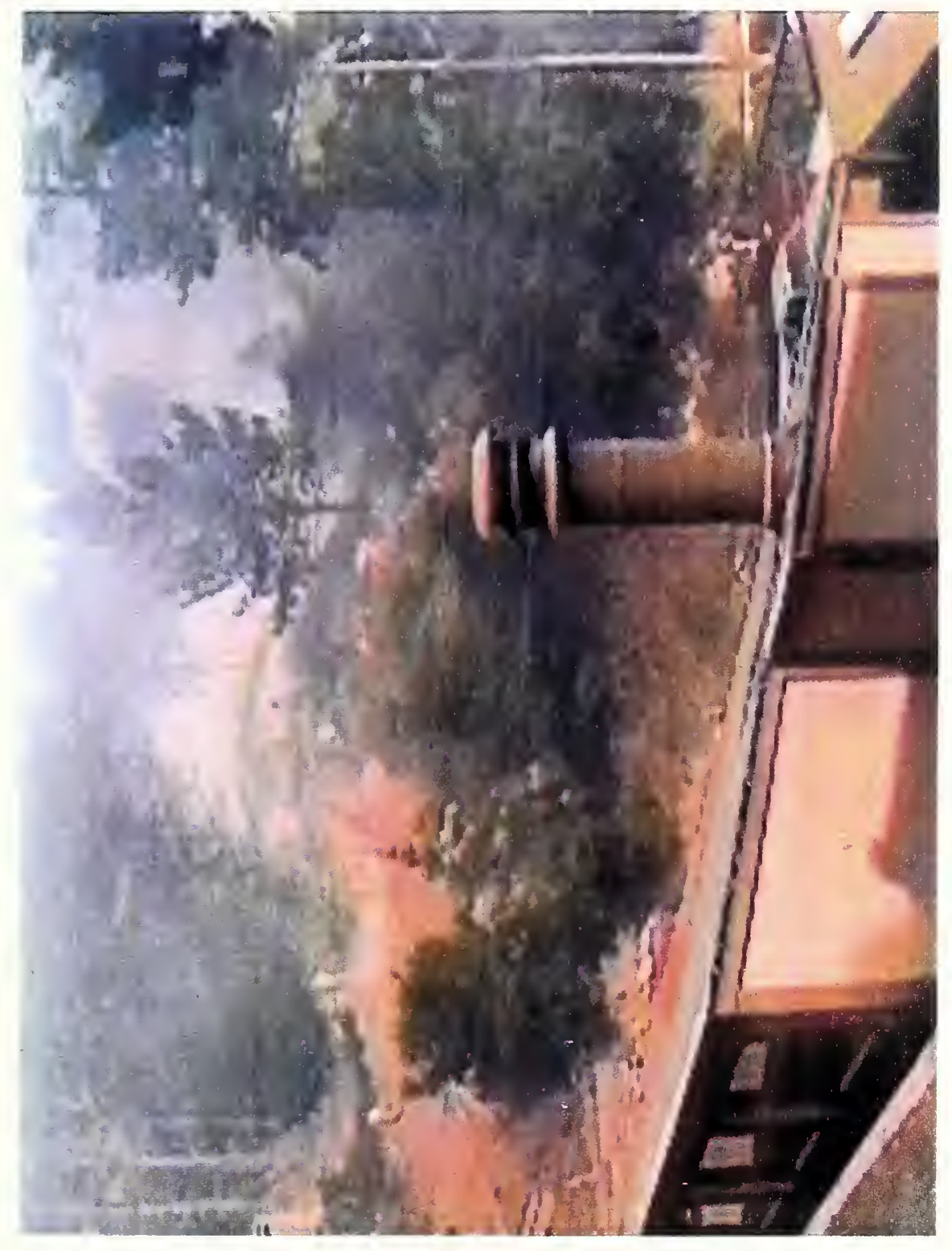

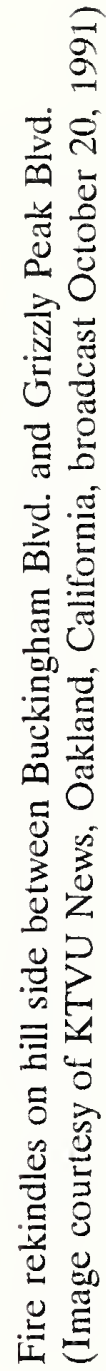

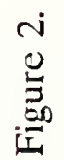




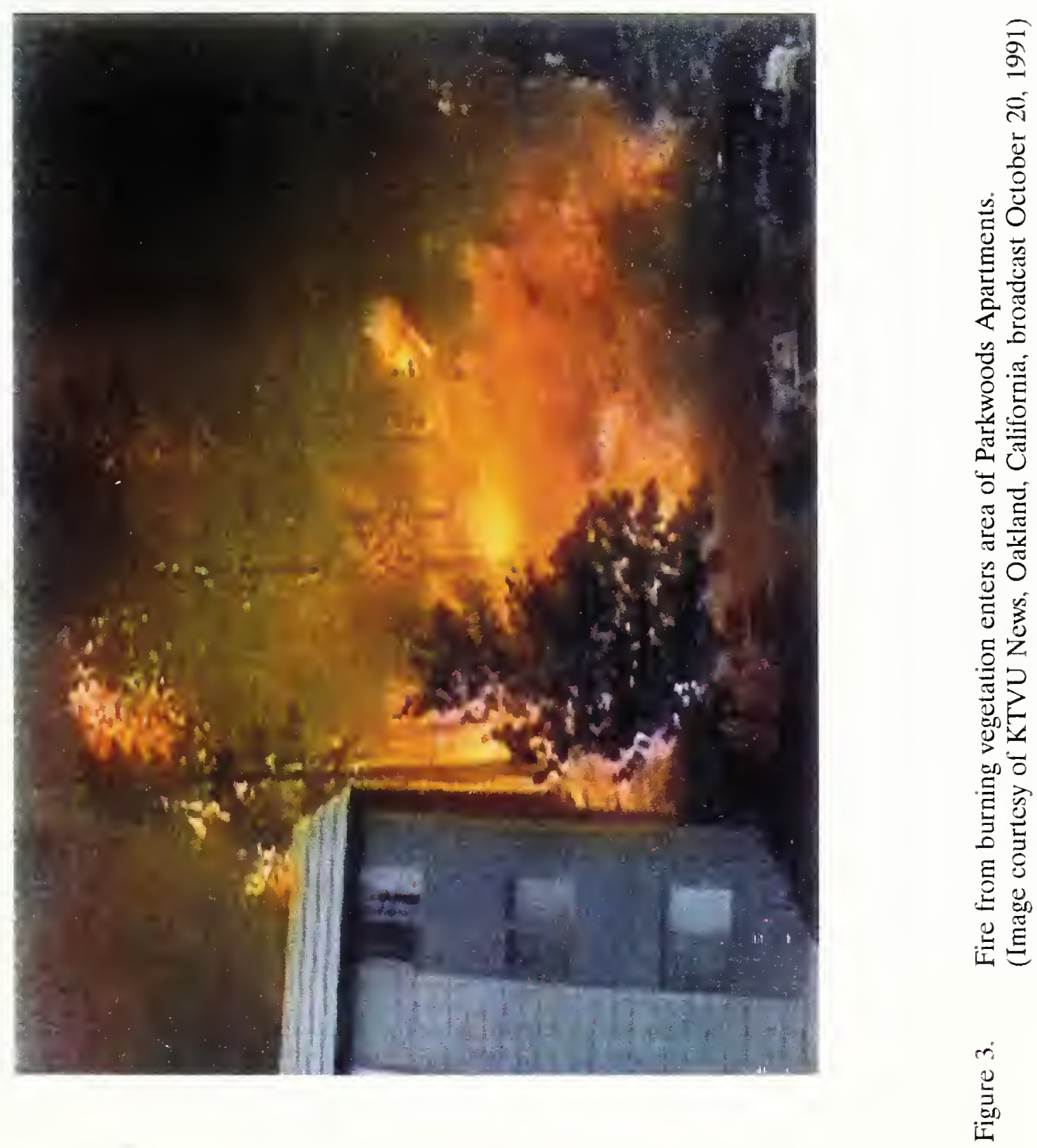



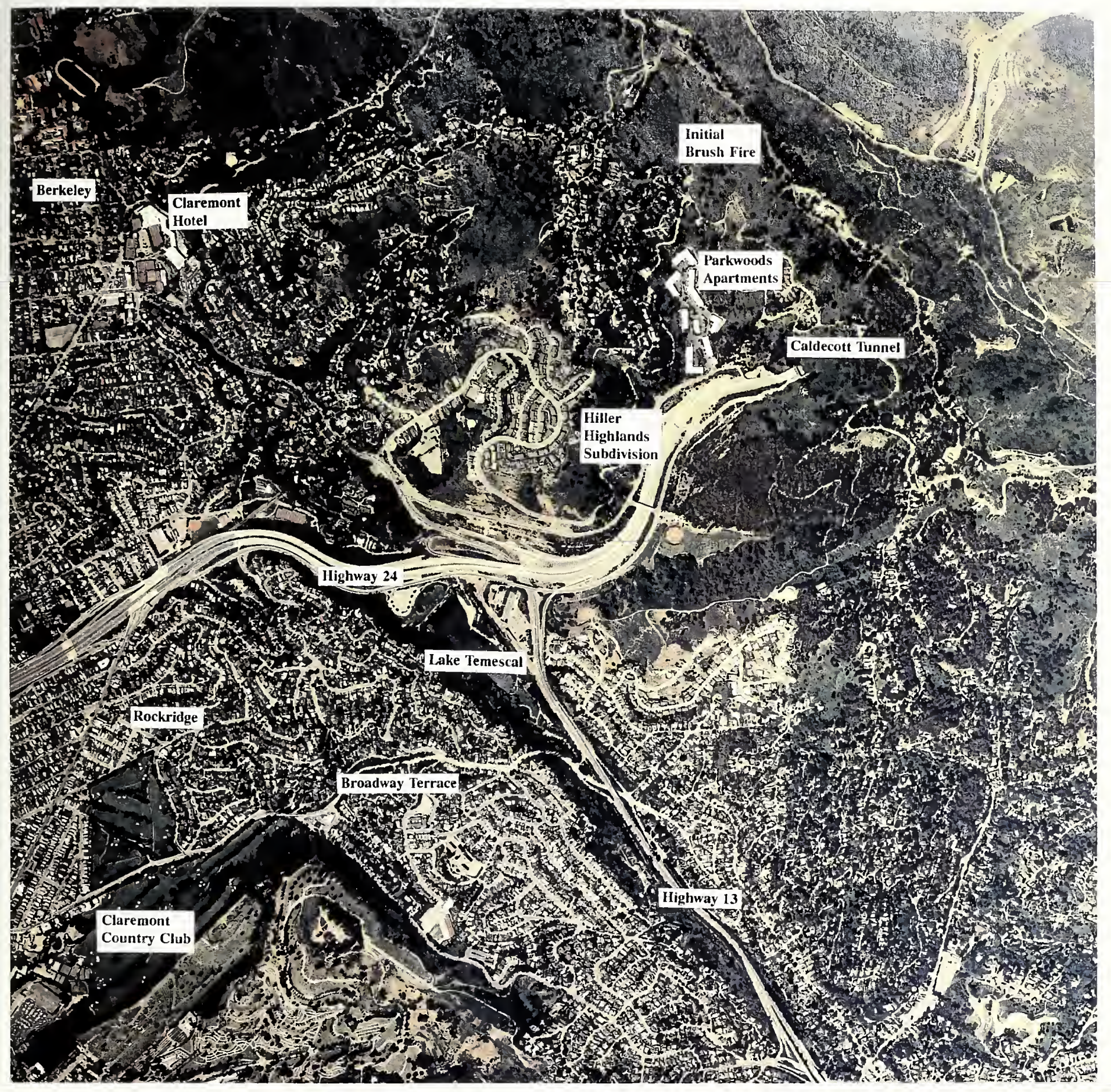

Figure 4. Aerial view of the Oakland and Berkeley hills on April 30, 1990. (Photograph from Pacific Aerial Surveys of Oakland, California) 



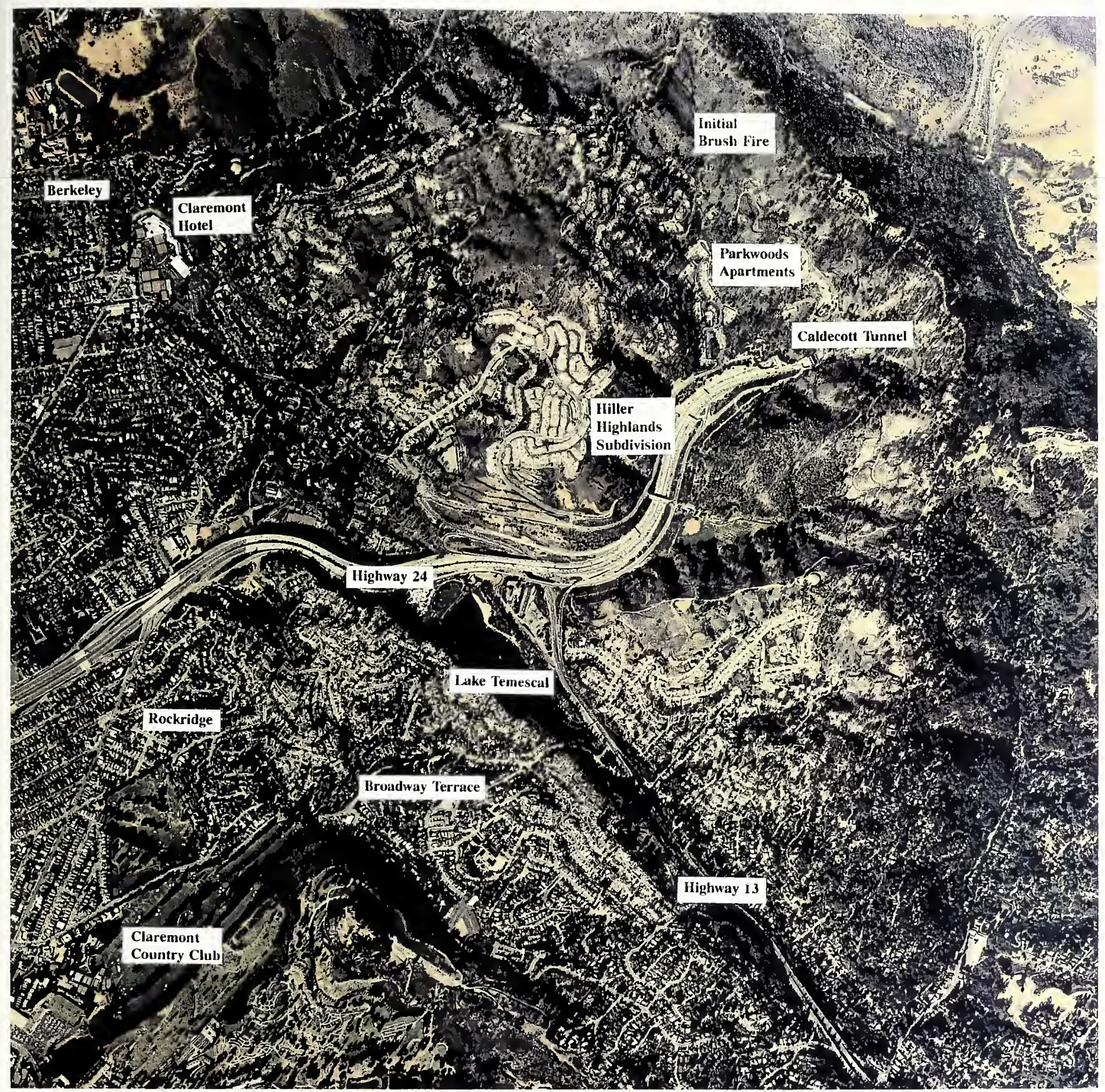

Figure 5. Aerial view of Oakland and Berkeley hills on October 23, 1991.

(Photograph from Pacific Aerial Surveys of Oakland, California) 


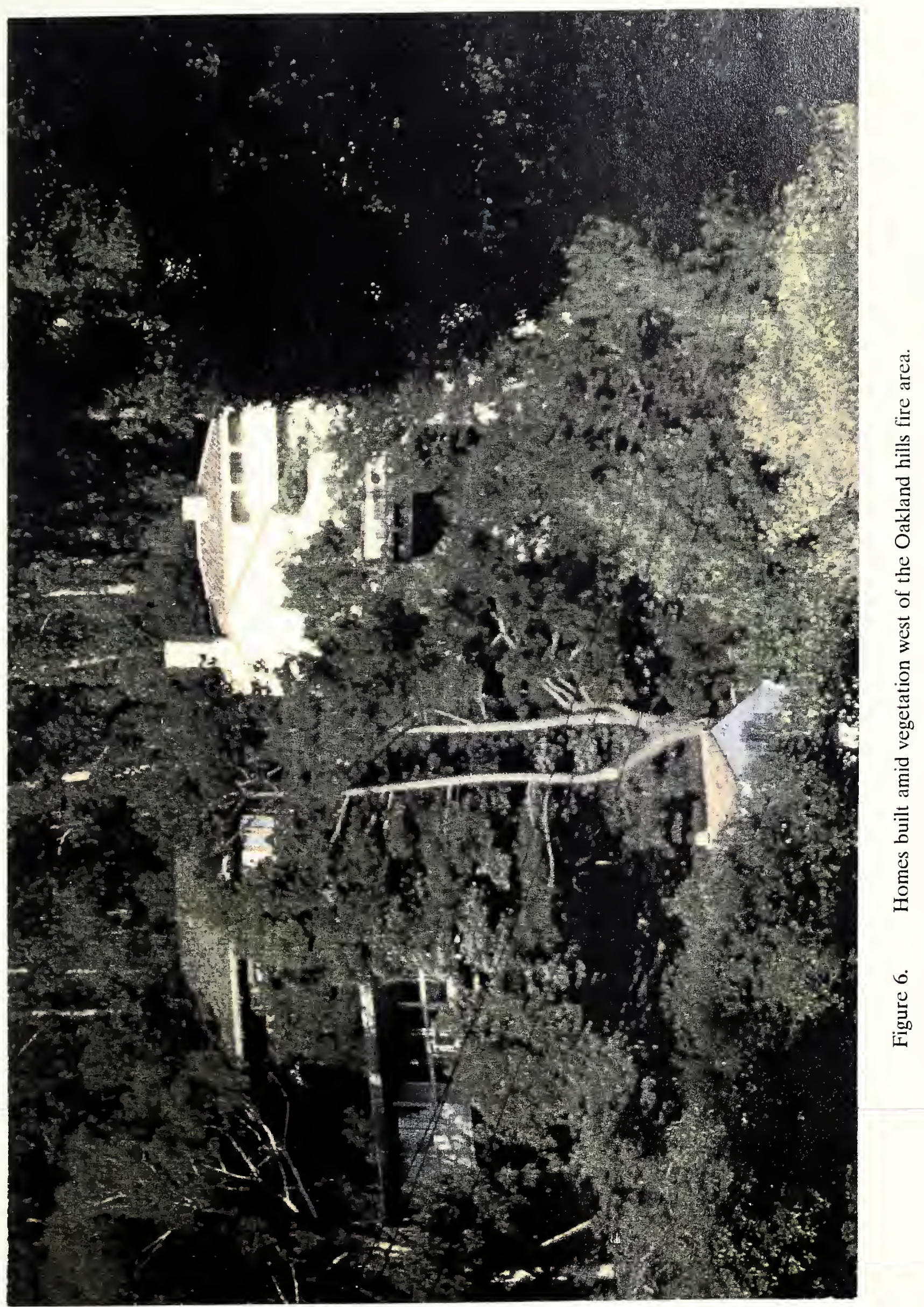





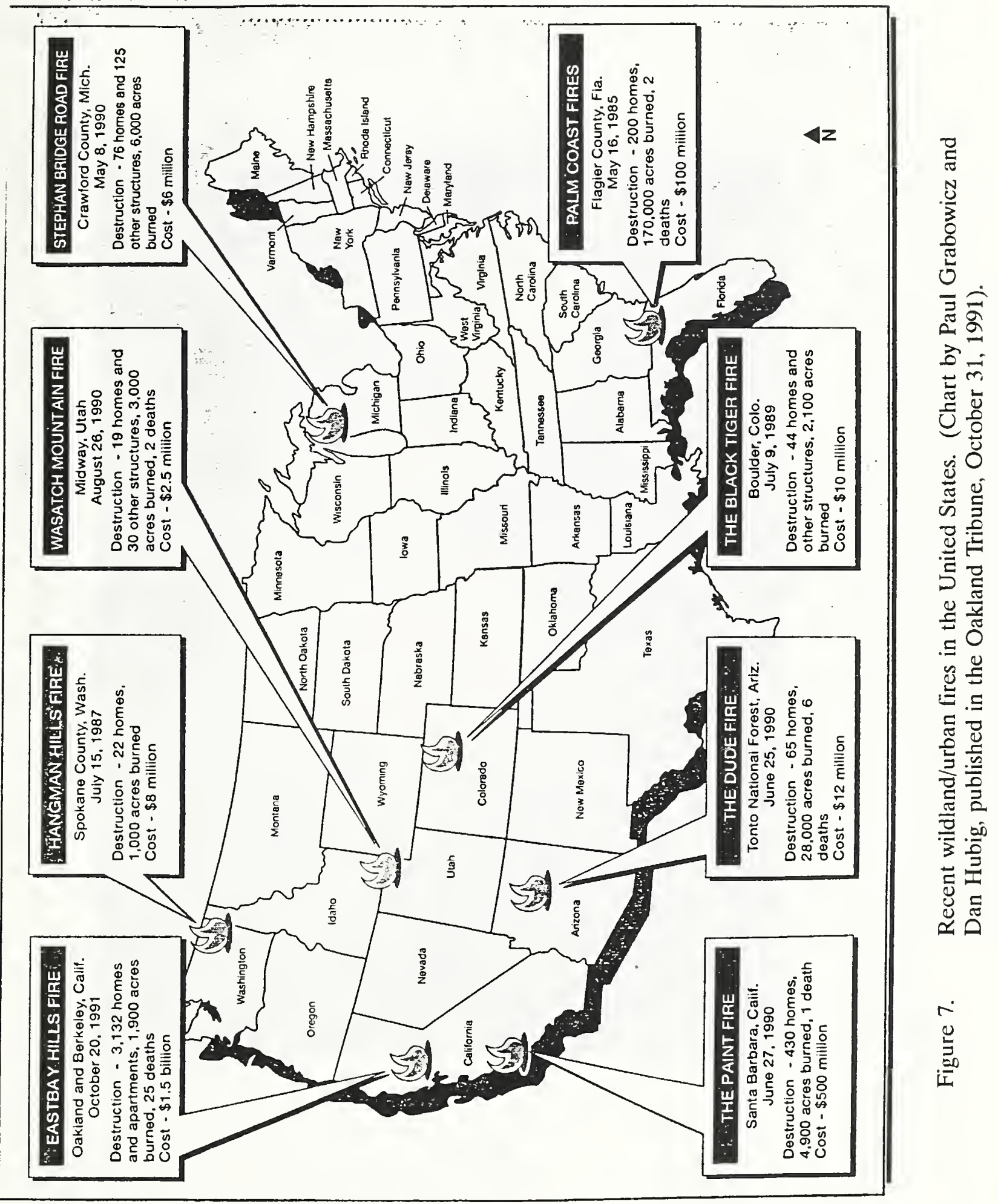





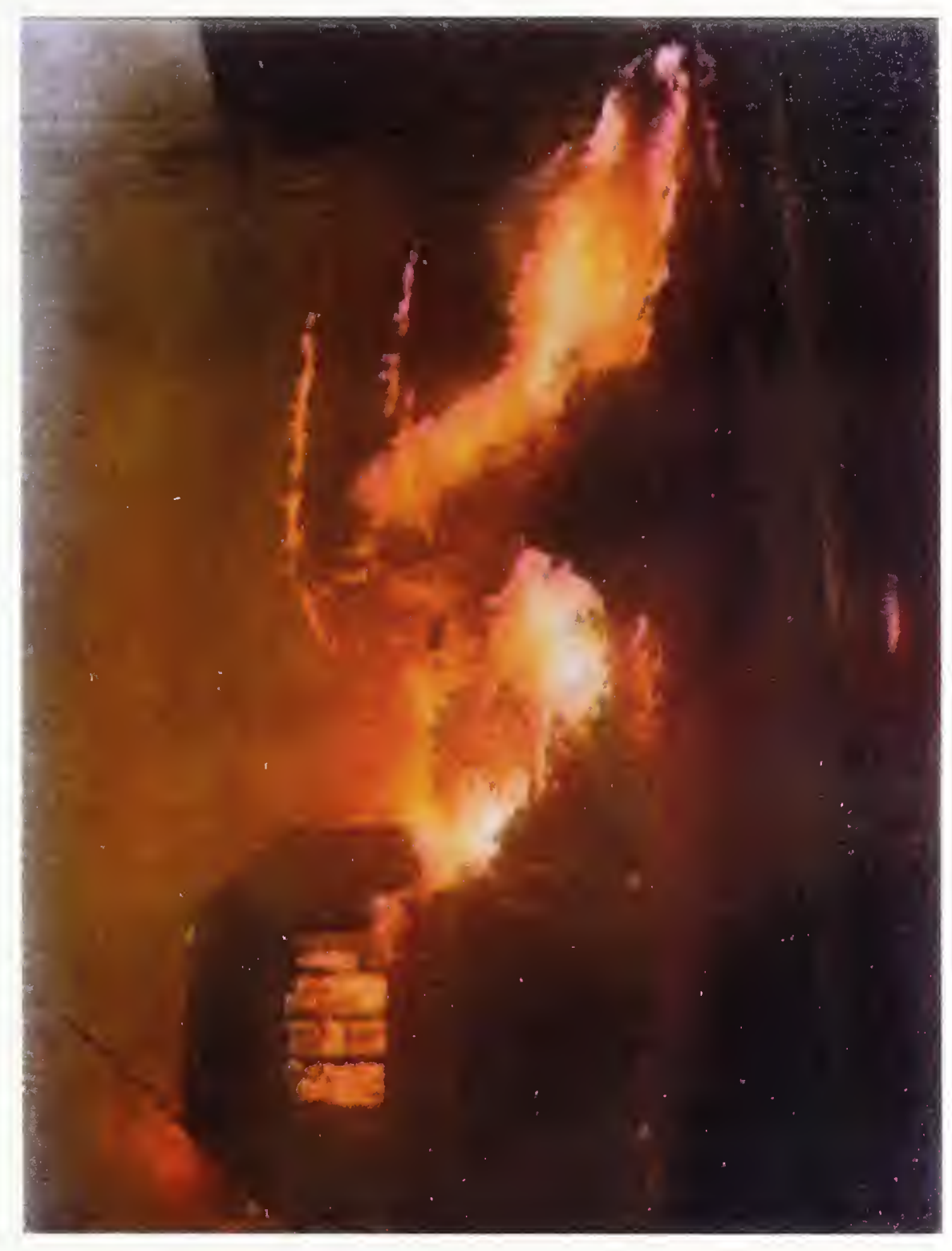

总

를

흘

范

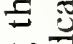

또ㅇㅝㅠ

. 들

כ

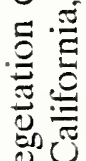

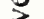

氜

응

苞

छิ

ह

?

可

कs

.

롤

잉

莺葍

递 



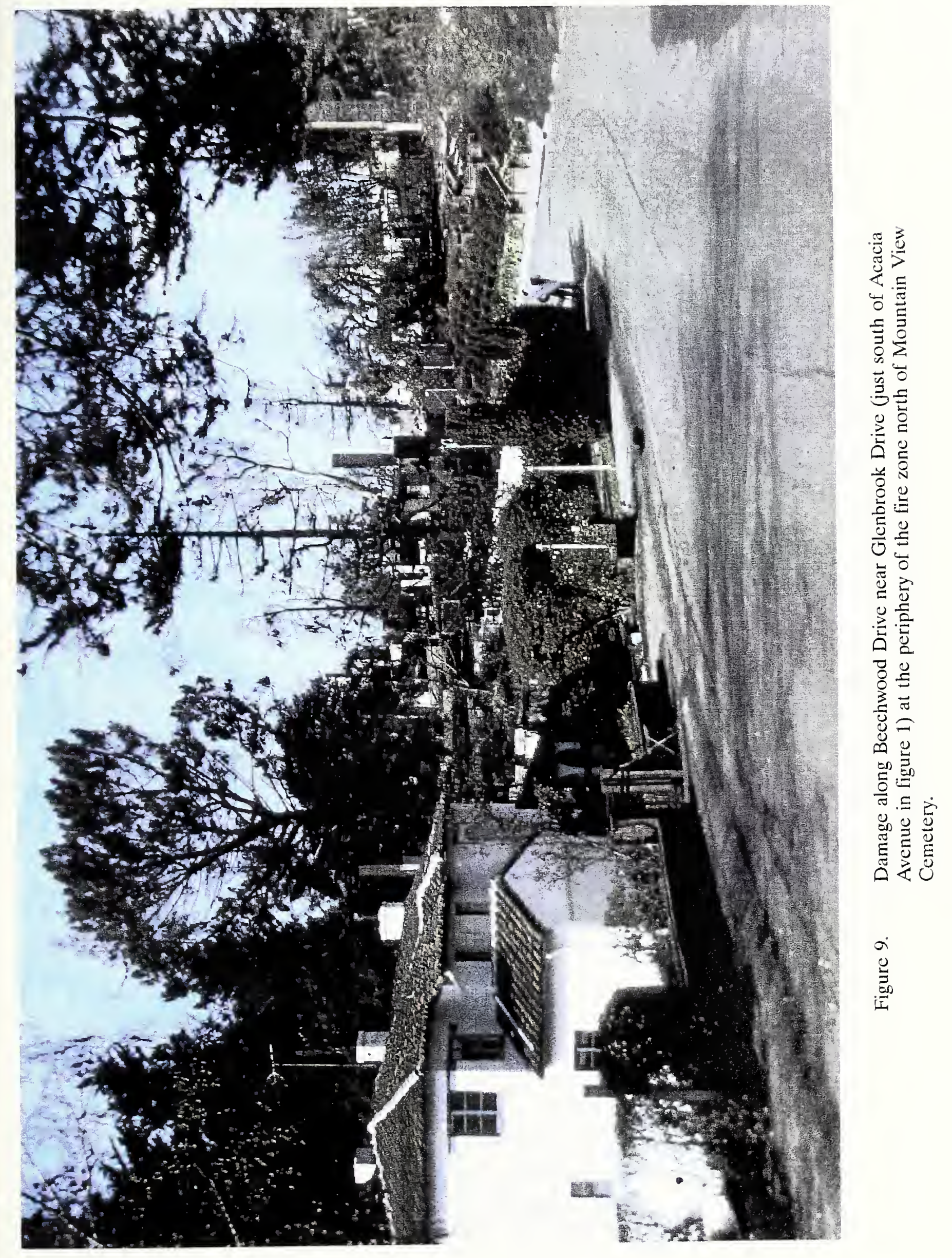





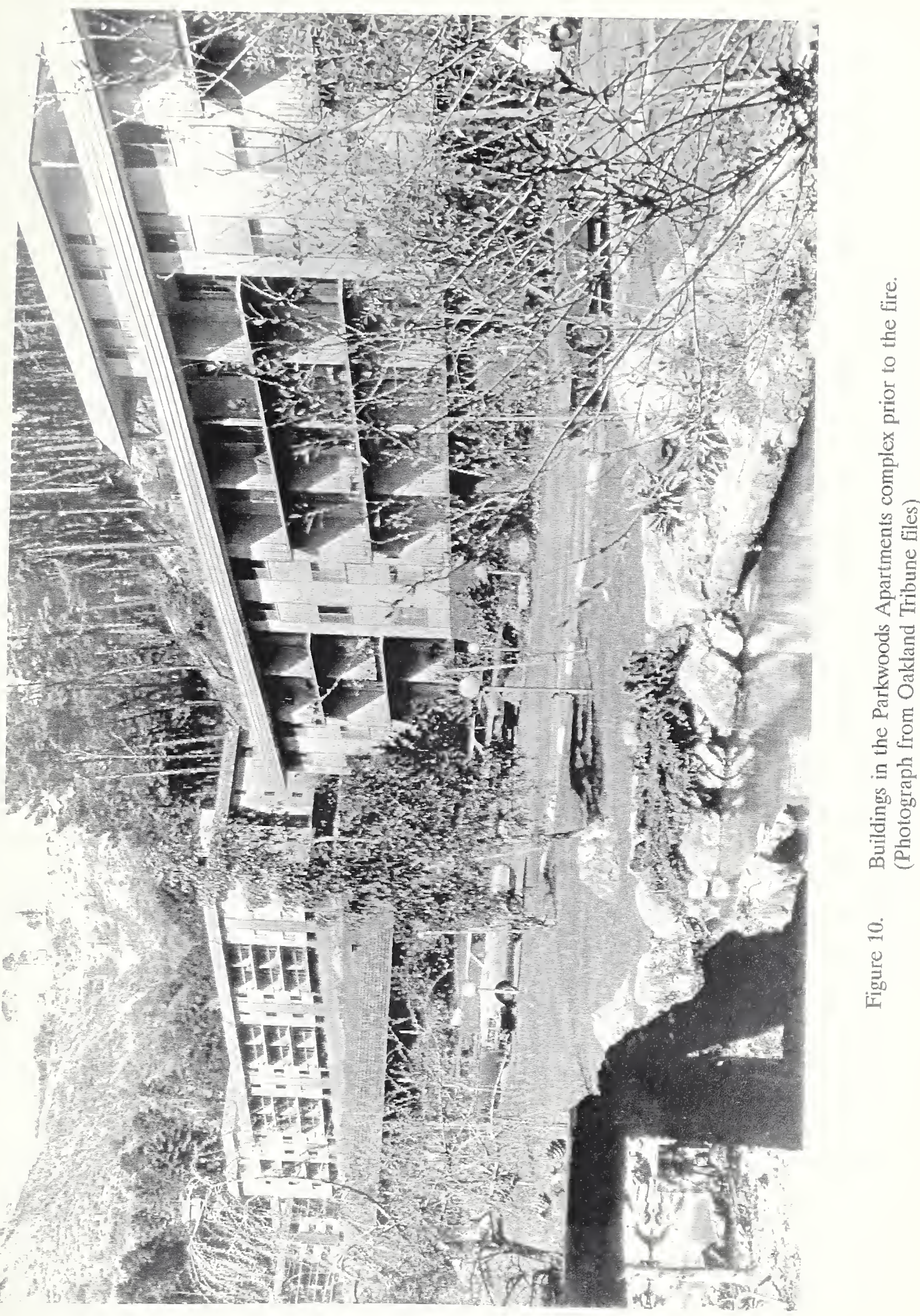





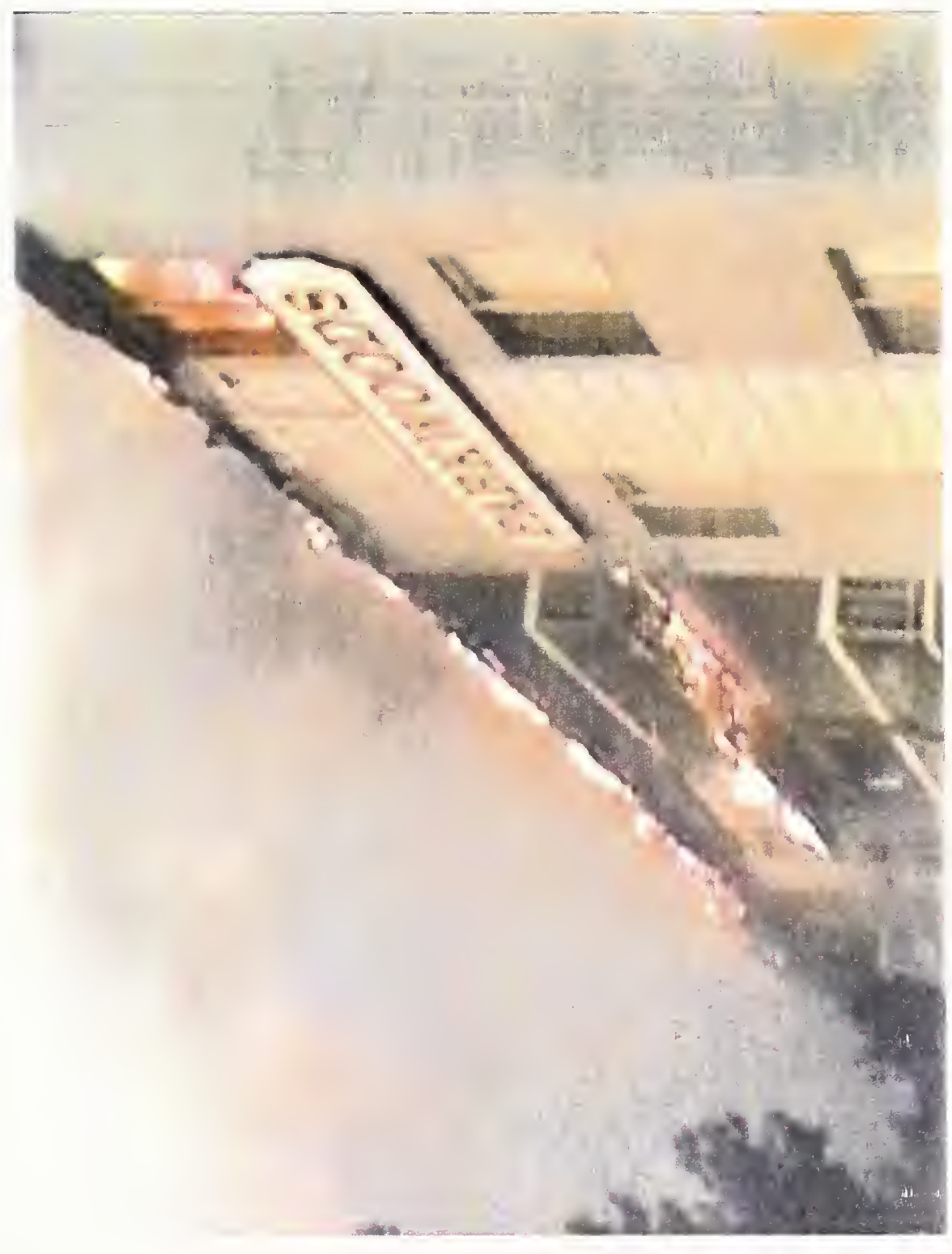

高

ㅇำ

ปั.

递苞

苛

콩ํㅇ

产

ํㅣㅁ

동

뭄

造

产

는

픈

들

岩

to

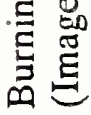

$\stackrel{2}{3}$ 




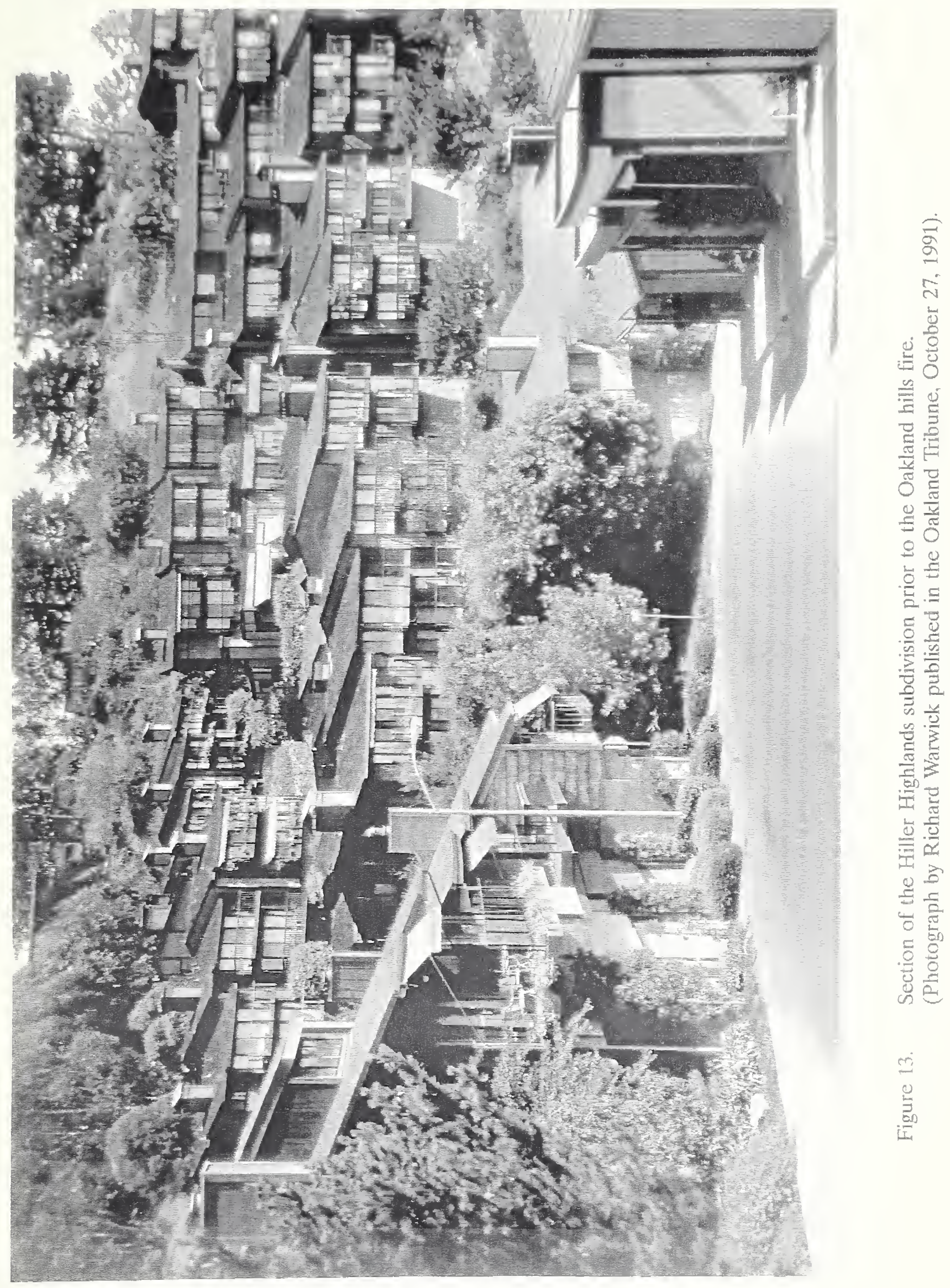





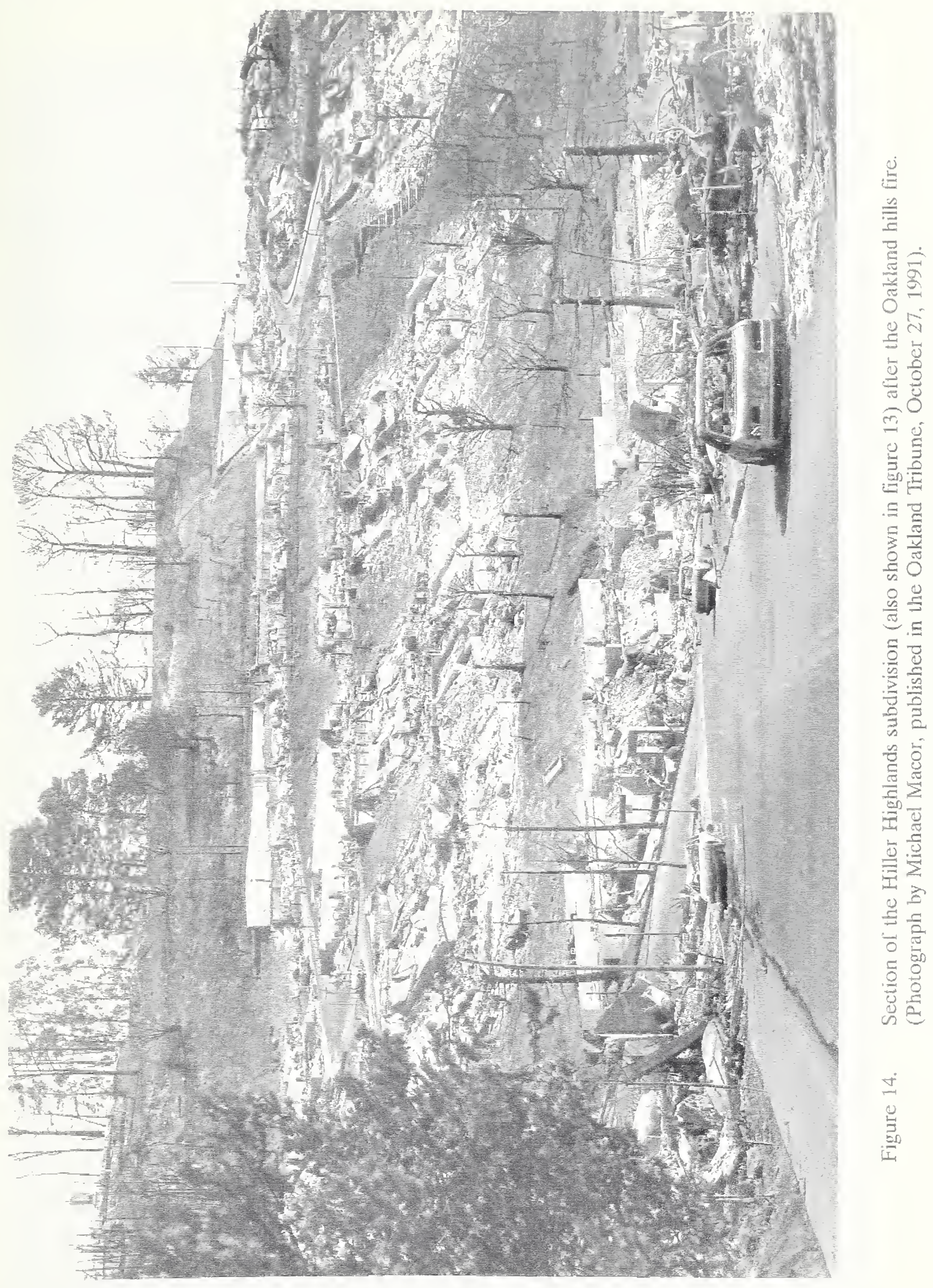





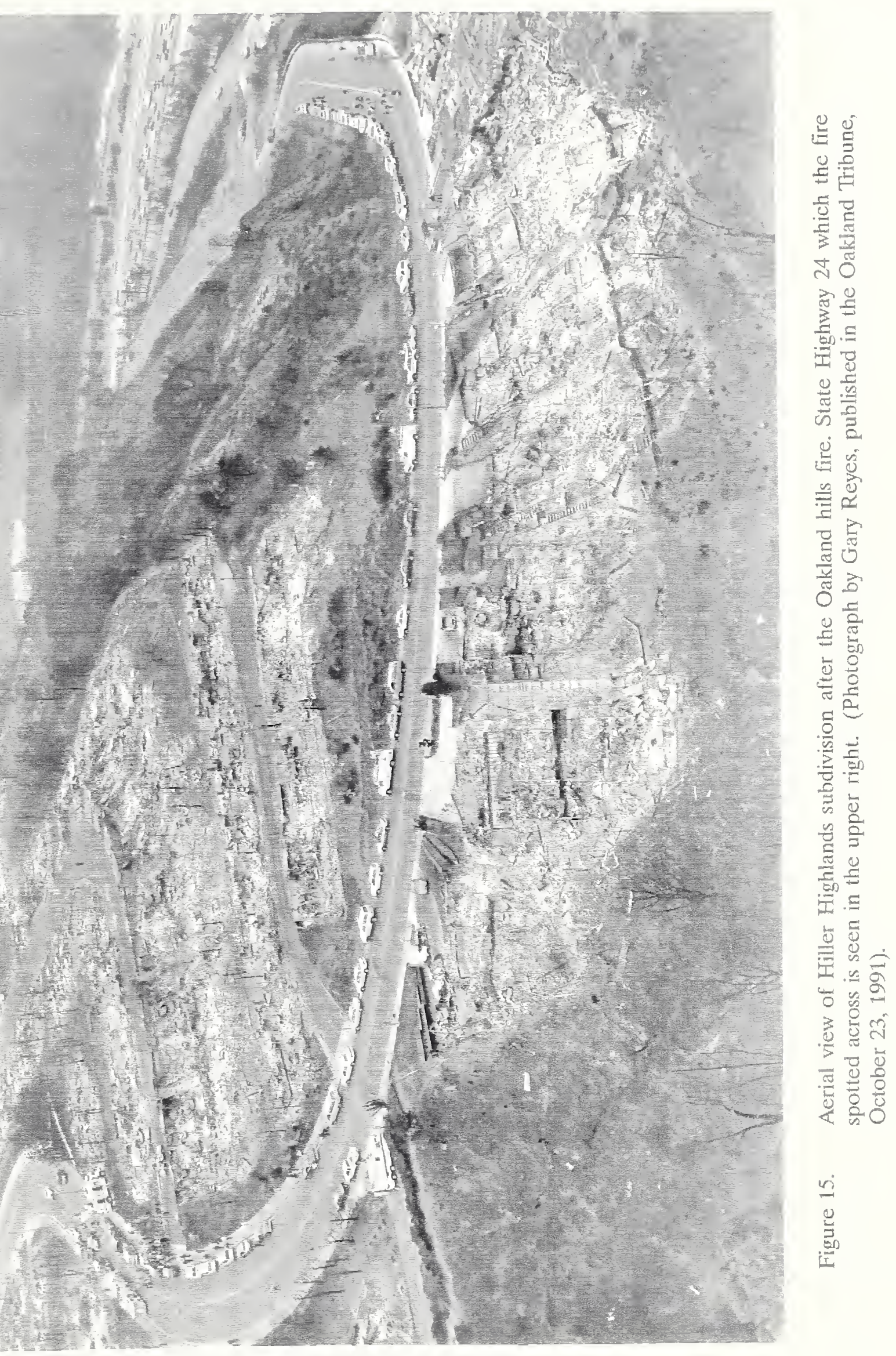





\begin{tabular}{|c|c|c|}
\hline \multirow{3}{*}{\multicolumn{2}{|c|}{$\begin{array}{l}\text { U.S. DEPARTMENT OF COMMERCE } \\
\text { NATIONAL INSTITUTE OF STANDARDS AND TECHNOLOGY }\end{array}$}} & $\begin{array}{l}\text { 1. PUBUCATION OR REPORT NUMBER } \\
\text { NISTIR } 4724\end{array}$ \\
\hline & & 2. PERFORMING ORGANIZATION REPORT NUMBER \\
\hline & & $\begin{array}{l}\text { 3. PUBUCATION DATE } \\
\text { November } 1991\end{array}$ \\
\hline \multicolumn{3}{|c|}{$\begin{array}{l}\text { 4. TITLE AND SUBTITLE } \\
\text { Preliminary Study of the } 1991 \text { Oakland Hills Fire and Its Relevance to Wood-Frame, Mult1- } \\
\text { Family Building Construction }\end{array}$} \\
\hline \multicolumn{3}{|c|}{$\begin{array}{l}\text { 5. AUTHOR(S) } \\
\text { Kenneth D. Steckler, David D. Evans, and Jack E. Snell }\end{array}$} \\
\hline \multirow{2}{*}{\multicolumn{2}{|c|}{$\begin{array}{l}\text { 6. PERFORMING OAGANIZATION (IF JOINT OR OTHER THAN MIST, SEE INSTRUCTIONS) } \\
\text { U.S. DEPARTMENT OF COMMERCE } \\
\text { NATIONAL INSTITUTE OF STANDARDS AND TECHNOLOQY } \\
\text { GATHERSBURG, MD } 20899\end{array}$}} & 7. CONTRACT/GRANT NUMBER \\
\hline & & 8. TYPE OF REPORT AND PERIOD COVERED \\
\hline \multicolumn{3}{|c|}{ 9. SPONSORING ORGANIZATION NAME AND COMPLETE ADDRESS (STREET, CITY, STATE, ZIP) } \\
\hline
\end{tabular}

10. SUPPLEMENTARY NOTES

11. ABSTRACT (A 200-WORD OR LESS FACTUAL SUMMARY OF MOST SIGNIFICANT INFORMATION. IF DOCUMENT INCLUDES A SIGNIFICANT BIBUOGRAPHY OR UTERATURE SURVEY, MENTION IT MERE.)

The purpose of this study was to establish the relevance, if any, of the Oakland hills wildland and suburban fire that occurred on October 20,1991, to the design of multi-family wood-frame housing in the United States (U.S.) and Japan. A group of fire scientists and experts in building practices from both countries studied the fire through inspections of the site and meetings with local fire and building officials. The high wind speed, proximity of flammable vegetation to structures, and the flammability of exterior construction materials were factors in the spread of the fire. The use of wood framing members in the construction of multi-family housing did not influence significantly the rate of spread or extent of the fire. The severity and duration of the exposure, from fires ignited both outside and inside of buildings, resulted in total destruction of most structures within the fire area, regardless of the type of construction.

12. KEY WORDS (6 TO 12 ENTRIES; ALPHABETICAL OADER; CAPITALIE ONLY PROPER NAMES; AND SEPARATE KEY WORDS BY SEMICOLONS)

apartments; fire investigations; fires; residential buildings; urban fires; wildland fires

13. AVAILABIUTY

13

UNUMITED

FOR OFFICIAL DISTRIBUTION. DO NOT RELEASE TO NATIONAL TECHMICAL INFORMATION SERVICE (NTIS).

ORDER FROM SUPERINTENDENT OF DOCUMENTS, U.S. GOVERNMENT PRINTING OFFICE, WASHINOTON, DC 20402.

ORDER FROM NATIONAL TECHMICAL INFORMATION SERVICE (NTIS), SPRINGFIELD, VA 22161.

\begin{tabular}{|l|} 
14. NUMBER OF PRINTED PAGES \\
34 \\
\hline 15. PRICE \\
\\
$\mathrm{A} 02$
\end{tabular}



